\title{
Democracia e Subsidiariedade
}

\author{
Rozangela Bertolo
}

\section{INTRODUÇÃO}

Subsidiariedade - conceito e origem

A investigação acerca da concepção de subsidiariedade, no tocante a suas origens e significação, sinaliza para a doutrina social da Igreja Católica e os documentos pontifícios, especialmente as Encíclicas Immortale Dei, do Papa Leão XIII, Quadragésimo Anno, do Papa Pio XI, e Mater et Magistra, do Papa João XXIII.

O Papa Leão XIII enunciou na Immortale Dei o antecedente do princípio afirmando a garantia frente ao poder do Estado da esfera familiar e local, comunal, e o âmbito que salvaguarda a dignidade e a vida dos cidadãos.

O princípio de filosofia social da Igreja, foi expresso pelo papa Pio XI, Encíclica Quadragésimo Anno (1931), indicando a necessidade e a importância de delegar-se às associações ou corpos intermediários o que estes podem realizar segundo o princípio da função supletiva ${ }^{1}$ dos poderes públicos.

\footnotetext{
'Veja-se os itens 78 a 80 da Encíclica Quadragésimo Anno, de Pio XI, no título 5 referente à Restauração da Ordem Social: “ 78. Ao falarmos na reforma das instituições, temos em vista sobretudo o Estado; não porque dêle só deva esperar-se todo o remédio, mas porque o vício do já referido "individualismo" levou as coisas a tal extremo, que, enfraquecida e quase extinta aquela vida social outrora rica e harmônicamente manifestada em diversos gêneros de agremiaçōes, quase só restam os indivíduos e o Estado. Esta deformação do regime social não deixa de prejudicar o próprio Estado, sôbre o qual recaem todos os serviços que as agremiações suprimidas prestavam e que verga ao pêso de negócios e encargos quase infinitos. 79. Verdade é, e a história o demonstra abundantemente, que devido à mudança de condições, só as grandes sociedades podem hoje levar a efeito o que antes podiam até mesmo as pequenas; permanece, contudo, imutável aquêle solene princípio da filosofia social; assim como é injusto subtrair aos individuos o que êles podem efetuar com a própria iniciativa e indústria, para o confiar à coletividade, do mesmo modo passar para uma sociedade maior e mais elevada o que sociedades menores e inferiores podiam conseguir, é uma injustiça, um grave dano e perturbaçāo da boa ordem social. O natural da sociedade e da sua ação é coadjuvar os seus membros, e não destruí-los nem absorvê-los. 80. Deixe, pois, a autoridade pública ao cuidado das associações inferiores aqueles negócios de menor importância, que a absorveriam em demasiado; poderá então desempenhar mais livre, enérgica e eficazmente o que só a ela compete, porque só ela o pode fazer: dirigir, vigiar, urgir e reprimir, conforme os casos e a necessidade requeiram. Persuadam-se todos os que governam de que quanto mais perfeita ordem hierárquica reinar entre as várias agremiaçōes, segundo êste princípio da função "supletiva" dos poderes públicos, tanto maior influência e autoridade terão êstes, tanto mais feliz e lisonjeiro será o estado da nação." (grifou-se) In Documentos Pontifícios Pio XI Sobre a restauração e aperfeiçoamento da ordem social (Quadragésimo ano) IV Edição, Petrópolis, Rio de Janeiro, São Paulo, Belo Horizonte : Vozes, 1957, p. 31 e 32 .
} 
Na Carta Encíclica "Mater et Magistra" (1961), ao tratar da Evolução da Questão Social, o Papa João XXIII reitera o princípio da subsidiariedade destacando que a ação dos poderes públicos deve ter o caráter de orientação, de estímulo, de coordenação, de suplência e de integração, inspirando-se no princípio da subsidiariedade formulado por Pio XI na Quadragésimo Anno².

Os referidos textos pontifícios manifestaram-se assinalando a importância dos chamados "corpos intermediários"'. Tratam da socialização no sentido da "multiplicação progressiva das relaçôes dentro da convivência social" comportando "a associação de várias formas de vida e de atividade, e a criação de instituiçóes jurídicas ${ }^{5}$ e como efeito e causa uma "crescente intervenção dos poderes públicos nos domínios mais delicados, como os da saúde, da instrução e educação... da orientação profissional, dos métodos de recuperação e readaptação dos indivíduos dalgum modo menos dotados"'. Ressaltam, também, a tendência natural dos seres humanos a originar uma grande variedade de grupos, associaçōes e instituições.

Para a adequada compreensão da subsidiariedade, faz-se necessário o exame das origens do princípio de modo a evitar uma perspectiva equivocada do ponto de vista histórico, especialmente tendo-se em mente a contínua releitura ou recepção de princípios, valores e normas?

A atuação subsidiária estatal proposta pela doutrina social da Igreja inspira-se na estrutura medieval canônica e nos mecanismos múltiplos de organização social e política existentes na sociedade medieval, cujo pensamento ressaltava, conforme Antônio Manuel Hespanha:

" a indispensabilidade de todos os órgãos da sociedade e, logo, da impossibilidade de um poder político 'simples', 'puro', não partilhado. Tão monstruoso como um corpo

\footnotetext{
${ }^{2}$ Documentos Pontifícios. João XXIII. Sôbre a recente evolução da questão social. Carta Encíclica "Mater e Magistra" Petrópolis, RJ : Vozes, 1961, p. 14.

${ }^{3}$ Veja-se o texto da encíclica Mater et Magistra: "62. Para o conseguir, requer-se, porém, que as autoridades públicas se tenham formado, e realizem praticamente, uma concepção exata do bem comum, êste compreende o conjunto das condiçóes sociais que permitem e favorecem nos homens o desenvolvimento integral da personalidade. E cremos necessário, além disso, que os corpos intermediários e as diversas iniciativas sociais, em que sobretudo procura exprimir-se e realizarse a socialização, gozem duma forma de autonomia efetiva relativamente aos poderes públicos, $e$ vão no sentido dos seus interesses específicos, com espírito de leal colaboração mútua e de subordinação às exigências do bem comum. Nem é menos necessário que ditos corpos se apresentem sob a forma de verdadeiras comunidades; isto é que os seus membros sejam considerados e tratados como pessoas, e estimulados a participar ativamente na vida associativa. 63. A s organizações da sociedade contemporânea desenvolvem-se, e a ordem dentro delas consegue-se, cada vez mais, graças a um equilibrio renovado: exigência, por um lado, de colaboração autônoma prestada por todos, individuos e grupos; e, por outro lado, coordenação no devido tempo e orientação promovidas pelas autoridades públicas." Documentos Pontifícios. Joāo XXIII. Sôbre a recente evolução da questão social. Carta Encíclica "Mater e Magistra". Petrópolis, RJ : Vozes, 1961, p. 17.

${ }^{4}$ Encíclica citada, p. 15.

${ }^{5}$ Op. cit., p. 15 e 16.

${ }^{6}$ Op. cit., p. 16.

${ }^{7} \mathrm{Com}$ o intuito de respeitar a lógica das fontes no sentido adotado por António Manuel Hespanha in Panorama histórico da cultura jurídica européia. Mira-Sintra, Portugal : Publicações Europa-América, 1997, p.46.
} 
que se reduzisse à cabeça, seria uma sociedade em que todo o poder estivesse concentrado no soberano. O poder era, por natureza, repartido; e, numa sociedade bem governada, esta partilha natural deveria traduzir-se na autonomia políticojurídica (iurisdictio) dos corpos sociais"s.

As múltiplas funções do Estado acentuam suas relações com a sociedade, notadamente a interação entre o poder central e os poderes periféricos ${ }^{9}$ e a questão da auto-organização da sociedade, da autonomia, da organização federal, da organização comunitária internacional.

A matéria, tributária do direito canônico, apresenta estreita vinculação com a democracia e com o pluralismo político.

O princípio ${ }^{10}$, tem aplicação no plano internacional, no plano nacional, no âmbito da intervenção do Estado na iniciativa privada, na discussão acerca da presença do Estado na economia e das cláusulas econômicas inseridas nos textos constitucionais.

Aplica-se nas relações de trabalho, na co-administração dos empregados nas empresas, no ensino, na planificação regional.

O termo subsidiariedade apresenta, como se pode defluir, uma polissemia, uma plurissignificação, sendo relevantes as noções de supletividade, de suplementariedade, de complementariedade.

O publicista francês Jean-Marie Pontier afirma que a subsidiariedade faz parte dos elementos da arquitetura do Direito Administrativo francês do século XX ao lado do princípio da legalidade e da responsabilidade, todavia, entre aqueles elementos não imediatamente perceptíveis mas indispensáveis ao edifício. Assevera ser a subsidiariedade uma noção mal conhecida, discreta e solitária. Não sendo um termo portador de uma significação precisa em direito.

Etimologicamente o termo e seus derivados provém do latim subsidium compreendendo um sentido de assistência, auxílio e subsidiarius designando o que é secundário, auxiliar ou supletivo. Das diferentes significaçōes do termo tem-se, de um lado, a idéia de secundariedade e, de outro, as idéias de supletividade e de complementariedade. Estas últimas significações estão em consonância com o

\footnotetext{
${ }^{8}$ HESPANHA, António Manuel.Op. cit., p. 61.

${ }^{2}$ Ver sobre $O$ assunto $O$ princípio de subsidiariedade - conceito e evolução, de José Alfredo de Oliveira Baracho, Rio de Janeiro: Forense, 1997.

${ }^{10}$ Para maiores detalhes em relação à essencial distinção entre princípios e regras consulte-se o capítulo que Eros Grau dedica ao tema em A ordem econômica na Constituição de 1988 (interpretação e critica). São Paulo: RT, 1990, p.92 e segs. O autor salienta a plurissignificação do termo princípio, conotando tanto princípios gerais do direito - proposição normativa por terem sido positivados em determinados ordenamentos jurídicos - como uma dimensão de peso e importância a comportar valoração (Dworkin). Salienta a distinção da regra pela estrutura peculiar, de representação de situação objetiva de hipótese à qual vinculam-se conseqüências jurídicas práticas - os seus efeitos - constituindo-se as regras na concreção dos princípios.
} 
enunciado contido nos documentos pontifícios e igualmente com o sentido dado aos direitos romano e canônico como subsidiários dos direito locais ${ }^{11}$.

\section{A-SUBSIDIARIEDADE, DEMOCRACIAE SOCIEDADE PLURALISTA.}

A constante evolução da sociedade contemporânea leva à discussão e ao exame dos conceitos de democracia e pluralismo e o papel dos grupos sociais.

De acordo com a etimologia, democracia é o governo do povo que a exerce diretamente ou por seus representantes. Suas origens remontam ao pensamento grego, em especial Platão no livro VIII da 'República' e Aristóteles em 'A Política'.

A idéia é indissoluvelmente ligada à de liberdade e igualdade. Evolui com as concepções liberais, de Locke, em seu 'Ensaio sobre o governo civil', de Montesquieu, com a célebre doutrina da separação dos poderes formulada em 'O espírito das leis', e de Rousseau com sua concepção de soberania popular na obra ' $O$ contrato social'.

Da crítica à democracia liberal e sua ênfase na liberdade e na igualdade abstrata e formal resulta a democracia social intrinsecamente vinculada à idéia de igualdade e justiça social. O avanço da técnica inaugura uma nova modalidade de democracia gerando questóes relativas à tecnocracia.

A Democracia Social, contrastando a Social Democracia, leciona Miguel Reale, é a nova forma assumida pelo liberalismo em uma sociedade pluralista que necessita compor em unidade três valores que são complementares: o do indivíduo, o da sociedade civil, com a livre expansão de seus grupos e categorias naturais, e o Estado ${ }^{12}$.

A democracia, o ideal democrático continua sendo força poderosa na transformação da sociedade, especialmente na realização e concretização de valores de convivência humana.

Norberto Bobbio afirma: "Para definir democracia são necessárias duas negações: a negação dopoder autocrático, em que consiste a participação, e a negação do poder monocrático, em que consiste opluralismo ${ }^{13}$.

O princípio da subsidiariedade é concernente à organização da sociedade civil e do Estado, rejeita a centralização, a concentração de poderes pela autoridade central, bem como o abandono dos grupos sociais à sua própria sorte, propondo a atuação supletiva do Estado.

$\mathrm{Na}$ ciência e na teoria política mais recente retorna a idéia de pluralismo como coexistência de diferentes ordens políticas, jurídicas, costumeiras, no mesmo âmbito da sociedade ${ }^{14} \mathrm{e}$ o pós-modernismo acentua as formas quotidianas, implícitas e informais de poder $^{15}$.

\footnotetext{
11 É por demais conhecida a recepção do direito romano-canônico, que ingressa como direito subsidiário aplicável nas lacunas dos direitos locais e muitas vezes com desprezo a estes. Ver acerca a questão o artigo "Romanismo e Bartolismo" no Direito Português, de Mário Júlio de Almeida Costa, in Boletim da Faculdade de Direito da Universidade de Coimbra, v. XXXVI, 1960, p. 16-43, e "Breve histórico do direito Reinícola", de Cândido Mendes de Almeida , in Revista da AJURIS, no. 7, 1976, p. 5-40.

${ }^{12}$ REALE, Miguel. Liberdade e democracia. São Paulo : Saraiva, 1987, p.8.

${ }^{13}$ BOBBIO, Norberto. As ideologias e o poder em crise. Brasília. Ed. Polis, Ed. UnB, 1990, p. 28.

${ }^{14}$ HESPANHA, op. cit., p. 24.
} 
O conceito de pluralismo não é novo. A idéia de pluralismo consiste na melhor possibilidade de governo de uma sociedade quando maior a repartição do poder. Norberto Bobbio destaca ser:

"Uma das formas tradicionais para distinguir um governo despótico de um governo não despótico é observar a maior ou menor presença dos chamados corpos intermediários e, mais precisamente, a maior ou menor distribuição do poder territorial e funcional entre governantes e governados."

Neste contexto as sociedades e as associações primárias ou ditas intermediárias tem papel preponderante na organização social e política estatal. O Estado visa atingir seus fins específicos com respeito à pessoa humana e aos chamados grupos primários ou intermediários ${ }^{17}$ - a família, o município, a comuna, as associações - que buscam seus fins por seus próprios meios, reforçando assim a autonomia destes grupos e limitando, por conseqüência, o poder político Estatal.

Bobbio identifica três aspectos quando fala em pluralismo ou sociedade pluralista: a) a constatação da complexidade das sociedades contemporâneas formadas por esferas particulares dotadas de relativa autonomia, tais como os sindicatos, os partidos, os grupos organizados, os grupos não organizados; b) a preferência quanto ao melhor modo de organização destas sociedades de forma a fazer com que o sistema político permita a expressão política aos vários grupos e camadas sociais através da participação direta ou indireta na formação da vontade coletiva; e c) esta forma de constituição consubstancia a antítese de toda forma de despotismo, em particular o totalitarismo ${ }^{18}$.

O autor lista as correntes autodefinidas como pluralistas, nascidas dos três mais importantes sistemas ideológicos atuais. Assim, o socialismo que se diz pluralista é o chamado guild-socialism, de Hobson, do jovem Laski, e de Cole, sendo que este último identificou a existência da democracia real na Grã-Bretanha nos grupos, nas comunidades menores, formais e informais e na sua capacidade de formar rapidamente diante das premências imediatas ${ }^{19}$.

Já o pluralismo da doutrina cristã enunciado no Códice di Malines contra o individualismo deificador do indivíduo e o coletivismo deificador do Estado, salienta o desdobramento da vida humana em um certo número de sociedades, além da sociedade política constituída pelo Estado, a família, as associações profissionais e de outra natureza, sociedades naturais e não naturais, a Igreja e a comunidade internacional. $O$ pluralismo da doutrina cristã apresentou-se de forma organicista e funcionalista ${ }^{20}$. Esta

\footnotetext{
15 Id. ibid., p 24.

${ }^{16}$ BOBBIO, op cit.,p. 15.

17 O termo denota grupos sociais que se encontram entre o individuo e o Estado.

${ }^{18}$ BOBBIO, op. cit., p. 16 . O autor diz sobre a polêmica acerca do pluralismo em uma sociedade socialista: "Os esforços do pensamento socialista e democrático voltaram-se para o primeiro objetivo (negação do poder autocrático) - alargamento da participação do poder político estreitamente ligado ao poder econômico - e ainda não para o segundo ( negação do poder monocrático)", p. 28.

${ }^{19}$ ld. ibid., p. 17 e 21.
} 
concepção de pluralismo social foi acolhida no art. $2^{\mathrm{o}}$ da Constituição italiana, reconhecendo e garantindo os direitos invioláveis do homem enquanto indivíduo e enquanto membro das formaçóes sociais ${ }^{21}$.

Por fim, o pluralismo liberal-democrático da sociedade norte-americana estruturalmente mecanicista e conflitualista, ${ }^{22}$ consubstanciado na existência de uma multiplicidade de centros de poder não completamente soberanos, assim definido por Robert Dahl: "Em lugar de um centro singular de poder soberano, devem existir muitos centros, mas nenhum deles deve ou pode ser inteiramente soberano"

A concepção pluralista americana encontra uma de suas matrizes na teoria dos grupos de Bentley, sem falar-se no que Bobbio denomina "mito do associonismo americano" proveniente de Tocqueville.

Existem várias formas de pluralismo, visualizando-se, entretanto, uma base comum de importância e valorização dos grupos sociais, ou seja, a mesma do princípio da subsidiariedade.

Duas idéias constituem o substrato do princípio da subsidiariedade: a primeira, de valorização dos corpos sociais intermediários na organização da sociedade e, a segunda, de atuação suplementar ou supletiva do Estado junto a estes grupos. $O$ princípio da subsidiariedade está ligado a outro princípio, o da unidade.

Constata-se que a subsidiariedade passa do âmbito da doutrina social da Igreja para o direito constitucional, para o direito administrativo e para o direito internacional e comunitário.

O artigo da Constituição italiana introdutor do pluralismo em sentido técnico e específico, como teoria dos grupos sociais, segundo Bobbio, é o $2^{\circ}$, ao dispor acerca da tutela do indivíduo não somente enquanto indivíduo, mas enquanto membro das formaçōes sociais ${ }^{24}$.

O texto da Constituição da República Federativa do Brasil de 1988 não traz menção expressa ao princípio da subsidiariedade. Todavia, pode-se identificar implicitamente o princípio, no caput do artigo $1^{\mathfrak{o}}$, ao estatuir que a República Federativa é formada pela união indissolúvel dos Estados e Municípios ${ }^{25}$ elencando entre seus fundamentos, no inciso V, o pluralismo político. Verifica-se, no artigo 205, que cuida da educação como direito de todos e dever do Estado e da família, promovida e incentivada com a colaboração da sociedade, com a previsão de programas

\footnotetext{
${ }^{20}$ Concebe os vários entes organizados em um sistema hierárquico e finalista.

21 la. ibid., p. 18.

${ }^{22}$ Id. ibid., p. 21 e 22. O modelo mecanicista e conflitualista parte da relação de conflito existente e considera o resultado, jamais definitivo de um equilíbrio de forças que se cindem e se recompõem continuamente.

${ }^{23}$ id. ibid., p. 18.

${ }^{24}$ BOBBIO, op, cit. p. 31 .

${ }^{25} \mathrm{O}$ disposto no art. $1^{\circ}$ da Constituição Federal de 1988 sanciona a autonomia política e administrativa do Município, destoando da concepção clássica de federalismo, no sentido deste não deter
} 
suplementares no inciso. VII e, ainda, com o sistema de colaboração entre os entes da federação conforme o artigo 211 e parágrafos.

O princípio de atuação subsidiária, supletiva, do Estado aplica-se especialmente à repartição de competências nos Estados federados e à descentralização com transferência destas competências às coletividades e organizações territoriais, nos Estados unitários.

\section{B - SUBSIDIARIEDADE, AUTONOMIA E FEDERALISMO}

O federalismo está assentado na autonomia dos Estados-membros, pressupõe governo próprio e distribuição de competências. A autonomia no Estado federal consubstancia-se no poder agir dentro de um determinado âmbito preestabelecido constitucionalmente ${ }^{26}$. A autonomia é distinta da soberania, caracterizando-se pela delimitação das áreas de decisão e ação sobre seus interesses pelo direito, quadro ou moldura estabelecida na Constituição Federal.

A essência do federalismo funda-se na repartição de competências. A natureza e o tipo histórico da federação ${ }^{27}$ irão delinear a forma e os limites da partição ${ }^{28} \mathrm{de}$ poderes entre a União e os Estados-membros, estabelecendo-se para as comunas os denominados assuntos de interesse local ${ }^{29}$.

Klaus Stern consigna como conseqüência da opção pela organização federal que " los espacios constiticionales de la Federación y de los Länder se contraponen de forma fundamentalmente autónoma". ${ }^{30}$

O Estado federal apresenta estrutura caracterizada pela desconcentração do poder no âmbito territorial ou seja, como leciona Lúcia Valle de Figueiredo: "a pluralidade de centros de poderes autônomos, coordenados pelo poder central, este sim exercendo a soberania externa. ${ }^{31}$

No sistema federativo os Estados-membros dispõem de autonomia para o exercício de competências estabelecidas na constituição caracterizando-se pela "união de coletividades políticas e unidades territoriais, vincadas pela detenção de autonomia, autonomia esta configurada, fundamentalmente, pela existência de distribuição de competências para cada esfera governamental e de estruturas de administração e governo próprias. ${ }^{32}$.

não deter representatividade na parlamento da União. Todavia indiscutivel que a medida reforça a autonomia dos poderes locais.

${ }^{26}$ Ver sobre a questão José Afonso da Silva, ao abordar a autonomia e intervenção, no seu Curso de direito constitucional positivo, São Paulo: RT, 1990.

${ }^{27}$ A federação originariamente resultou da união de entidades políticas, inicialmente independentes e distintas a exemplo dos Estados Unidos da América, Suiça e Alemanha.

${ }^{28}$ PONTES DE MIRANDA prefere a expressão 'devolução' de competências aos Estados-membros ou Províncias, Comunas ou Municípios, em seus Comentários à constituição de 1946. Tomo II, Rio de Janeiro: Borsoi, 1960, no título 'Da organizaçāo federal', p. 339 e segs.

${ }^{29}$ A expressão remonta o medievo e encontra-se na legislaçāo e textos constitucionais contemporâneos como expressão do âmbito de autonomia das comunas locais.

${ }^{30}$ STERN, Klaus. Derecho del Estado de la República Federal Alemana. Madrid : Centro de Estudios constitucionales, 1987, p. 118.

${ }^{31}$ FIGUEIREDO, Lucia Valle. "Competências administrativas dos Estados e Municípios". Revista de Direito Administrativo. Rio de Janeiro, 207: 1-9, jan./mar., 1997. 
Por óbvio, a conformação constitucional da autonomia está diretamente ligada às características histórico, econômico e social de cada Estado.

Acerca da originalidade da federação norte-americana e da importância das comunas locais, salienta Tocqueville:

"Na maior parte das naçôes européias, a existência política começou pelas regióes superiores da sociedade e se comunicou, pouco a pouco, e sempre de maneira incompleta, às diversas partes do corpo social. Na América, pelo contrário pode-se afirmar, que a comuna foi organizada antes do condado, o condado antes do Estado, o Estado antes da União." ${ }^{33}$ (grifou-se)

$\mathrm{O}$ aspecto da organização estatal que diz respeito à autonomia municipal ${ }^{34}$ representa a contraposição das entidades locais ao poder central. A autonomia municipal, por vezes é modelada de forma meramente administrativa, outras vezes com índole político-administrativa.

Francisco Campos lembra as cidades gregas que estabeleciam o seu regime próprio de governo, refere os municípios romanos e as comunas medievais salientando as diversas concepções do conceito de autonomia, seus distintos temperamentos, restrições e alcance.

O autor salienta a distinção das realidades e estruturas jurídicas historicamente consagradas, o que é necessário se ter presente no exame das formas de autonomia contemporâneas:

"O município romano não é o mesmo município grego não é o mesmo município da Idade Média, e, no entanto, a autonomia municipal que se procura defender agora vem se filiar a essas instituições históricas, e o argumento decisivo, invocado em favor dessa autonomia, é justamente o espírito do governo local, a função histórica representada pela autonomia local na formação do Estado moderno". ${ }^{35}$

Acerca das comunas dos Estados Unidos afirma Tocqueville:

"... é na comuna que reside a força dos povos livres. As instituiçóes são para a liberdade aquilo que as escolas primárias são para a ciência; pois colocam ao alcance do povo, fazendoo gozar do seu uso pacífico e habituar-se a servir-se dela. Sem instituiçóes comunais pode uma nação dar-se um governo livre, mas não tem o espírito da liberdade ${ }^{36}$

A execução dos serviços locais constitui o cerne da administração própria. No texto constitucional brasileiro, a cláusula da interesse local veio substituir a do peculiar interesse como definidora do âmbito de atuação dos municípios. A

${ }^{32}$ BERTOLO, Rozangela Motiska.. Direito Urbanístico e Constituição. Dissertação de Mestrado. Porto Alegre: UFRGS, 1998, p. 47.

${ }^{33}$ TOCQUEVILLE. Alexis de. A democracia na América. Belo Horizonte: Ed. Itatiaia, São Paulo: Ed. da USP, 1987, p. 39.

${ }^{34}$ Estudei mais detalhadamente a matéria no título A autonomia do Município no Brasil na Dissertação de Mestrado citada. 
predominância do interesse tem sido balizadora na identificação do que seja interesse local face à dificuldade diante da sobreposição ou interseção de áreas de atuação e de interesses.

José Alfredo de Oliveira Baracho, examinando o federalismo alemão e o princípio da subsidiariedade, destaca as várias revisóes ocorridas nos últimos anos na ordem política e econômica na Alemanha objetivando maior liberdade de participação, com o federalismo como componente essencial do governo democrático ${ }^{37}$, elencando a doutrina, segundo o autor, pontos essenciais na justificação do federalismo:

"1) o federalismo preserva a diversidade histórica e a individualidade; 2) facilita a proteção das minorias; 3) aplica o princípio da subsidiariedade; 4) o federalismo é um meio de proteção da liberdade;5) o federalismo encoraja e reforça a democracia, facilitando a participação democrática; a eficiência é também, considerada como uma das razões que justificam ofederalismo." 38 (grifou-se)

A experiência alemã do Estado Federal Democrático tem no federalismo e no parlamentarismo dois princípios basilares devendo-se ter presente as suas particularidades, condiçóes sociais, estrutura econômica e desenvolvimento ${ }^{39}$.

O autor indica Gustav Gundlach considerado criador e expositor na doutrina alemã no que respeita aos aspectos sociais e filosóficos do princípio da subsidiariedade e, politicamente, Oswald von Nell-Breuning vinculando o referido princípio com o conceito de federalismo, revelando que os elementos constitutivos da subsidiariedade estão em sua estrutura governamental, compreensão conduzente a inferir-se o estreito liame entre o federalismo e o princípio da subsidiariedade.

A descentralização ocorre tanto dentro da estrutura administrativa dos órgãos públicos como na organização federativa do estado.

Sobre a descentralizaçáo administrativa cabe o registro de Tocqueville de servir a centralização administrativa para enfraquecer as nações que a elas se submetem, tendendo a diminuir entre elas o que denominou "espírito de cidade":

"Certos interesses são comuns a todas as partes da nação, tais como a elaboração das leis gerais e as relaçōes do povo com os estrangeiros. Outros interesses são especiais a certas partes da nação, tais como, por exemplo, os empreendimentos comunais. Concentrar num mesmo lugar ou numa mesma mão o poder de dirigir os primeiros é instituir o que eu chamaria de centralização governamental. Concentrar da mesma maneira o poder de dirigir os segundos é o que eu denominaria da centralização administrativa" ${ }^{40}$.

A descentralização comporta, também a adoção de estruturas regionais compostas de mais de um Estado e regióes intra-estaduais, assim como é a forma que

\footnotetext{
${ }^{35}$ CAMPOS, Francisco. Direito constitucional. Rio de Janeiro: Freitas Bastos, 1956, v. II, p.28.

36 TOCQUEVILLE, op. cit., p. 54.

${ }^{37}$ BARACHO, op. cit. p. 43.

${ }^{38}$ Id. ibid., p. 43.
} 
os Estados unitários utilizam para conferir maior autonomia às suas comunidades locais e regionais.

Jean-Marie Pontier aponta a descentralização como um domínio de aplicação da subsidiariedade: 'Plus précisément, ce principe trouve à s'appliquer aux relations entre les organes centraux et les organes locaux, il commanda, dans une mesure Qui reste à verifier, la décentralisation". ${ }^{41}$

Em relação à política de descentralização o mesmo autor assinala que o princípio da subsidiariedade é um dos princípios a partir dos quais se pode justificar e explicar as medidas de descentralização. Aceitar o princípio significa admitir a idéia conforme a qual as autoridades locais devem dispor de certos poderes. É um instrumento de liberdade uma vez que condena a absorção de todos os poderes pela autoridade central. Sustenta Pontier:

"Le principe de subsidiarité peut se résumer, dans le domaine de la décentralisation, de maniére très simple: laisser le plus de liberté et de pouvoirs aux collectivités territoriales sans rien sacrifier de ce Qui fait l'essentiel de la fonction de l'État". ${ }^{42}$

Inserto no princípio da subsidiariedade está a descentralização concretizada no Estado Federado, na desconcentração de poderes no Estado Unitário mediante políticas de descentralização ${ }^{43} \mathrm{e}$, igualmente, na descentralização nas estruturas administrativas dos órgãos públicos. O princípio indica uma necessidade de equilíbrio entre o poder central e os poderes locais e regionais.

Os grupos sociais não podem ser desconsiderados quer se tratando da organização estatal, quer se tratando da sociedade internacional.

O princípio da subsidiariedade supóe a divisão de competências, a descentralização e a cooperação das diversas esferas das estruturas tanto estatal como comunitária.

\section{C - A SUBSIDIARIEDADE NO DIREITO INTERNACIONAL E COMUNITÁRIO}

Ao lado da perspectiva das relações internas dos Estados e dos chamados corpos intermediários releva a questão da subsidiariedade nas relações internacionais.

${ }^{39}$ Id. ibid., p. 46.

${ }^{40}$ ld. Ibid., p. 73.

${ }^{4 i}$ Op. cit.

${ }^{42}$ Op. cit.

${ }^{43} \mathrm{~A}$ propósito da descentralização administrativa às coletividades locais na França ver os seguintes artigos: MORAND-DEVILLER, Jacqueline e MONCHAMBERT, Sabine. "Les nouvelles responsabilités des collectivités locales". Revue du Droit Public et de la Science Politique en France et a L'Étranger. 1988, p. 991-1058. REGOURD, Serge. "De la décentralisation dans ses rapports avec la démocratie" Revue du Droit Public et de la Science Politique en France et a $L$ 
O direito internacional público tem como finalidade regrar as relações entre Estados soberanos e, também, entre os organismos internacionais e os Estados que deles fazem parte.

A vida exterior dos Estados e de seus cidadáos cada vez mais é balizada pela política e regulações jurídicas derivadas de organizações internacionais globais ou setoriais. A integração mediante adesão caracterizam estes entes, estes organismos.

O universo da aplicação da subsidiariedade é ampliado pela existência de organizações internacionais tais como as Nações Unidas e a Organização dos Estados Americanos. O mesmo ocorre com as organizaçōes regionais, a exemplo da Comunidade Econômica Européia, e sub-regionais como o Mercosul.

No direito internacional encontra-se a alusão à competência subsidiária da Assembléia Geral das Naçōes Unidas e aos órgãos subsidiários das Nações Unidas ${ }^{44}$.

À semelhança da organização interna dos Estados o princípio da subsidiariedade encontra aplicaçáo na sociedade internacional em razão do indispensável respeito às particularidades e potencialidades dos entes da comunidade internacional o que tem reflexos importantes no âmbito da validade e dos efeitos dos tratados.

Diante de estruturas nacionais e supranacionais, diante da pluralidade de direitos aplicáveis, diante de realidades históricas, econômicas e sociais distintas verifica-se a importância da aplicação do princípio da subsidiariedade a da necessária existência de equilíbrio entre Estados nacionais.

A ocorrência de agrupamentos de Estados em estruturas supranacionais é possível, não somente pela manifestação expressa dos governos mas, também, do consentimento da população envolvida pela política e decisões da futura organização.

É especialmente no direito comunitário que a subsidiariedade se torna noção fundamental.

A ciência, a prática, o direito e a política do comunitarismo decorrem da constituição de "comunidades de Estados" organizadas posteriormente ao pós-guerra sob as normas de integração constituindo uma nova realidade política e jurídica contemporânea ${ }^{45}$.

Este fenômeno gerou uma nova disciplina jurídica, o direito comunitário. A ordem jurídica criada pelo tratado internacional da Comunidade Européia constitui o direito da Comunidade Européia que é distinto, do direito internacional e também do sistema de direitos nacionais ${ }^{46}$ internos. Tem por escopo fundamental regular as relações entre a entidade supranacional comunitária e os Estados que a integram.

A professora Harriet Chistiane Zitscher - referindo que o Tratado de Maastrich fundador da União Européia, abrangendo a comunidade Européia, a moeda única e a cooperação intergovernamental nas áreas da política externa e interna - consigna que o receio de vários Estados membros em firmar um tratado ampliador das competências

'Étranger. 1990, p. 961-987. CAILLOSSE, Jacques. "La décentralisation. Mode d'emploi". Revue du Droit Public et de la Science Politique en France et a L'Étranger. 1988, p.1229-1249.

${ }^{44}$ BARACHO, op. cit. p 25.

45 Id. Ibid. p.21. 
dos órgãos de uma entidade européia cada vez mais centralizada determinou a incorporação expressa do princípio da subsidiariedade (artigo 3-b) com o intuito de equilibrar os poderes da Comunidade Européia ${ }^{47}$.

O Direito comunitário supõe uma atribuição de competências ao ente comunitário em matérias e finalidades específicas. O princípio da subsidiariedade constitui hoje um dos fundamentos da União Européia. Os Estados integrantes concordam em atribuir à entidade comunitária parcela de competência que antes detinham exclusivamente em razão de sua soberania

A subsidiariedade determina que a concessão de competências, em matérias não exclusivas à União Européia, tão somente ocorra se o fim pretendido não puder ser atingido, suficientemente, no plano dos Estados que a integram e se, cumulativamente, a atuação comunitária viabilizá-lo de melhor forma.

O disposto no supramencionado artigo $3-\mathrm{b}$ apresenta três elementos fundamentais: um limite preciso de ação da Comunidade traçado pelo Tratado e seus fins; uma atuaçáo supletiva comunitária no âmbito de competências não exclusivas, quando o fim pretendido não puder ser realizado, de maneira suficiente, pelos Estados participantes, e limitação da ação comunitária ao necessário para atingir os objetivos do Tratado.

Estes três elementos, que traduzem a essência da subsidiariedade, são adequados às outras organizações comunitárias, a serem constituídas ou que se encontram em distintas fases de implantação.

\section{CONCLUSÃO}

Neste trabalho examinou-se o princípio da subsidiariedade, sua aplicabilidade na auto-organização da sociedade, sem esgotar as possibilidades de aplicação do instituto.

Suas origens tem como fonte o direito canônico e a doutrina social da igreja. A subsidiariedade vincula-se ao princípio democrático e ao pluralismo político-social.

Envolve questóes de natureza histórico-filosófica, política, econômica e jurídica tanto no plano interno, como na organização comunitária e internacional.

Nas várias formas de pluralismo visualiza-se uma base comum de importância e valorização dos grupos sociais, ou seja, o mesmo fundamento do princípio da subsidiariedade.

Os suportes doutrinários do princípio da subsidiariedade, quanto à estrutura governamental, conduzem ao federalismo como aplicação da subidiariedade.

O princípio da subsidiariedade está presente nas questōes de cooperação das diversas esferas de ação social no pertinente à autonomia, à descentralização e à repartição de competências no sistema federativo.

${ }^{46}$ Veja-se o artigo "Integração jurídica na Europa", da professora Harriet Chistiane Zitscher, 
No que respeita à estrutura administrativa a adoção do princípio conduz à descentralização.

A subsidiariedade tem aplicação nos Estados Unitários através da descentralização e delegação de poderes às organizações territoriais e comunais.

O princípio também é informador da ordem jurídica internacional e comunitária. $\mathrm{Na}$ adoção de sistemas ou modelos jurídicos de organização do Estado e de organizaçōes e entes internacionais o princípio da subsidiariedade auxilia a compor de forma dinâmica três valores que se imbricam ${ }^{48}$ : a) o indivíduo, b) a sociedade civil e os diversos grupos sociais que a compóem e, $\mathrm{c}$ ) os Estados e comunidades de Estados, visando o bem comum e a justiça social.

publicado na Revista da Faculdade de Direito da UFRGS. 1999. p 63-78.

47 ZITCHER, op. cit.

${ }^{48}$ No sentido de implicaçāo e polaridade conforme a teoria tridimensional do direito de Miguel Reale. 


\section{Bibliografia}

ALARCÓN GARCLA, Gloria. Autonomia municipal, autonomia financeira. Madrid : Civitas, 1995.

ALMEIDA, Cândido Mendes de. "Breve histórico do direito Reinícola", Revista da AJURIS, no. 7, 1976. p. 5-40.

ANDRADE, José Carlos Vieira de. O dever de fundamentação expressa de actos administrativos. Coimbra : Almedina, 1992.

ARISTÓTELES. A política. São Paulo. EDIPRO, 1995. (Série Clássicos).

ÁVILA, Humberto Bergmann. "A distinção entre princípios e regras e a redefinição do dever de proporcionalidade". Revista de Direito administrativo. Rio de Janeiro. V. 215, jan./mar. 1999, 151-179.

BARACHO, José Alfredo de Oliveira. O princípio de subsidiariedade-conceito e evolução. Rio de Janeiro : Forense, 1997.

BERTOLO, Rozangela Motiska. Direito urbanístico e constituição. Dissertação de Mestrado. Porto Alegre: UFRGS, 1998.

BIZEAU, Jean-Pierre. "Pluralisme et Démocratie". Revue du Droit Public et de la Science Politique en France et a L'Etranger. v. 2, 1993, p. 513-542.

BOBBIO, Norberto. As ideologias e o poder em crise. Brasília : Ed. UnB : São Paulo: Polis, 1990.

CAILLOSSE, Jacques. “La décentralisation. Mode d'emploi”. Revue du Droit Public et de la Science Politique en France et a L'Etranger. 1988, p. 1229-1249.

CAMPOS, Francisco. Direito Constitucional. Rio de Janeiro: Freitas Bastos, v. II, 1956.

CANOTILHO, Direito constitucional. Coimbra : Almedina 1993.

CORREIA, Fernando Alves. Formas jurídicas de cooperação intermunicipal. Boletim da Faculdade de Direito da Universidade de Coimbra, 1984, p.61-128.

COSTA, Mário Júlio de Almeida. "Romanismo e Bartolismo", Boletim da Faculdade de Direito da Universidade de Coimbra, v. XXXVI, 1960, p. 16-43,

FIGUEIREDO, Lucia Valle. "Competências administrativas dos Estados e Municípios". Revista de Direito Administrativo. Rio de Janeiro, 207: 1-9, jan./mar., 1997.

GRAU, Eros Roberto. A ordem econômica na constituição de 1988 (interpretação e crítica). São Paulo : RT, 1990.

HESPANHA, António Manuel. Panorama histórico da cultura jurídica européia. Mira-Sintra, Portugal : Publicações Europa-América, 1997.

JOÃO XXIII, Sobre a recente evolução da questão social (Mater et Magistra). Petrópolis : Vozes, 1961.

. Pacem in terris. Rio de Janeiro: Vozes, 1963. (comentada). 
1963. V. II.

. As encíclicas sociais de. Rio de Janeiro: Ed. MEC e José Olímpyo,

LARENZ, Karl. Metodologia da ciência do direito. Lisboa : Calouste Gulbenkian, 1983.

MORAND-DEVILLER, Jacqueline e MONCHAMBERT, Sabine. "Les nouvelles responsabilités des collectivités locales". Revue du Droit Public et de la Science Politique en France et a L'Etranger. 1988, p.991-1058.

PIO XI. Sobre a Restauração e aperfeiçoamento da ordem social. (Quadragésimo ano). Petrópolis, Rio de Janeiro, São Paulo, Belo Horizonte : Vozes, 1957.

PONTES DE MIRANDA. Comentários à constituição de 1946. Rio de Janeiro: Borsoi, 1960.

PONTIER, Jean-Marie. "La subsidiarité en droit administratif". Revue du Droit Public et de la Science Politique en France et a L'Etranger. v.6, nov./dez., 1986, p. 1515. 1537.

REALE, Miguel. Teoria do Direito e do Estado. São Paulo: Saraiva, 1984. . Liberdade e democracia. São Paulo : Saraiva, 1987

REGOURD, Serge. "De la décentralisation dans ses rapports avec la démocratie. - genèsse d'une problematique". Revue du Droit Public et de la Science Politique en France et a L'Etranger. v. 4, 1990, p.961-985.

ROMI, Raphaël. "Chonique de Droit Public de L'environnement L'administration de l'environnement entre décentralisation et déconcentration. Revue du Droit Public et de la Science Politique en France et a L'Etranger. v. 6, 1992, p. 1771. 1792.

SILVA, José Afonso da. Curso de direito constitucional positivo. São Paulo: RT, 1990.

STERN, Klaus. Derecho del Estado de la República Federal Alemana. Madrid: Centro de Estudios Constitucionales, 1987.

TOCQUEVILLE, Alexis de. A democracia na América. Belo Horizonte : Ed. Itatiaia, São Paulo: Ed. da USP, , 1987.

ZITCHER, Harriet Chistiane. "Integração jurídica na Europa”. Revista da Faculdade de Direito da UFRGS. 1999, p. 63-78. 